\title{
Pengaruh Struktur Modal, Ukuran Perusahaan, Dan Profitabilitas Terhadap Harga Saham (Studi Kasus Pada Sub Sektor Makanan Dan Minuman Yang Terdaftar di Bursa Efek Indonesia)
}

\author{
Khomeiny Yunior \\ Universitas Prima Indonesia \\ khomeinyyunior@gmail.com \\ JenniferWinata \\ Universitas Prima Indonesia \\ jenniferwinata09@icloud.com
}

\section{Olivia}

Universitas Prima Indonesia olivia.ov774@gmail.com

\section{Saut Parttuppuan Sinaga}

Universitas Prima Indonesia

Sautsinaga82@gmail.com

\begin{abstract}
Abstrak
Penelitian ini dilakukan pada perusahaan sub sektor makanan dan minuman yang terdaftar di Bursa Efek Indonesia. Penelitian ini bertujuan untuk menguji dan menganalisis pengaruh Struktur Modal, Ukuran Perusahaan dan Profitabilitas terhadap Harga Saham. Metode penelitian yang digunakan dalam penelitian ini menggunakan metode pendekatan deduktif, jenis penelitian adalah kuantitatif yang bersifat deskriptif. Jumlah populasi dalam penelitian ini berjumlah 26 perusahaan dengan menggunakan teknik purposive sampling sehingga sampel menjadi 10 perusahaan. Metode analisis yang digunakan dalam penelitian ini adalah metode regresi linier berganda dan uji asumsi klasik. Hasil penelitian ini menunjukkan secara simultan Struktur Modal, Ukuran Perusahaan dan Profitabilitas berpengaruh terhadap Harga Saham pada perusahaan sub sektor makanan dan minuman yang terdaftar di Bursa Efek Indonesia periode 2014-2018, dengan hasil $F_{\text {hitung }}=34,694>F_{\text {tabel }}=2,81$ dan signifikan $0,000<0,05$. Secara parsial 1) Struktur Modal berpengaruh dan signifikan terhadap Harga Saham, 2) Ukuran Perusahaan berpengaruh dan signifikan terhadapHarga Saham dan 3) Profitabilitas berpengaruh dan signifikan terhadap Harga Saham. Hasil analisis koefisien determinasi diperoleh nilai Adjusted $\mathrm{R}^{2}$ sebesar 0,674 yang artinya variasi variabel Profitabilitas yang dapat dijelaskan oleh variasi variabel Struktur Modal, Ukuran Perusahaan dan Profitabilitas adalah sebesar 67,4\% sedangkan sisanya sebesar 32,6\% dijelaskan oleh variabel bebas lainnya.
\end{abstract}

Kata Kunci Struktur Modal, Ukuran Perusahaan, Profitabilias dan Harga Saham 


\section{PENDAHULUAN}

Sekarang ini dunia bisnis berkembang pesat kemudian menciptakan suatu persaingan antar perusahaan. Untuk mengantisipasi persaingan tajam sehingga perusahaan dihadapkan pada tuntutan bersaing. Perusahaan selalu mampu bertahan dengan menerbitkan saham untuk diperjualbelikan di pasar modal Indonesia (www.idx.co.id). Pasar modal Indonesia berperan penting menjadi sarana bagi masyarakat untuk berinvestasi. Bagi perusahaan, BEI ini dapat membantu perusahaan dalam hal untuk memperoleh tambahan modal apabila perusahaan telah go public sehingga masyarakat dapat melakukan transaksi atas saham emiten tersebut.

Harga saham perusahaan selalu mengalami kenaikan bahkan penurunan. Nilai emiten-nya terjadi kenaikan akibat harga saham tinggi. Penurunan nilai emiten mengakibatkan turunnya harga saham. Naik turunya harga saham di pasar modal menjadi fenomena menarik berhubungan keadaan perusahaan. Menurut Jogiyanto (2013:160), Nilai pasar adalah harga saham yang terjadi di pasar bursa pada saat tertentu yang ditentukan oleh pelaku pasar. Nilai pasar ini ditentukan oleh permintaan dan penawaran saham bersangkutan di pasar bursa.

Perusahaan selalu memiliki struktur modal baik internal maupun eksternal yang digunakan untuk membiayai kegiatan operasinya. Struktur modal berkaitan dengan harga saham tercermin pada nilai debt to equity ratio mempunyai hubungan yang negatif terhadap harga saham. Menurut Kasmir (2015:157), "Debt to Equity Ratio merupakan rasio yang digunakan untuk menilai utang dengan ekuitas. Rasio ini dicari dengan cara membandingkan antara seluruh hutang, termasuk utang lancer dengan seluruh ekuitas."Semakin tinggi rasio ini menunjukkan bahwa semakin besar jaminan yang digunakan dengan modal sendiri sehingga akan membuat semakin tinggi resiko yang akan dihadapi investor yang pada akhirnya investor akan meminta tingkat keuntungan yang tinggi juga. Hal ini menunjukkan bahwa dengan semakin besarnya rasio hutang, harga saham cenderung bergerak turun.

Harga saham ini dipengaruhi oleh ukuran perusahaan. Biasanya ukuran perusahaan ini diukur dengan total aktiva. Bagi perusahaan yang memiliki total aktiva yang besar dianggap mencapai tahap kedewasaan dimana arus kas perusahaan sudah positif serta memiliki prospek yang baik dalam jangka waktu panjang. Ukuran perusahaan besar memiliki harga saham tinggi sedangkan perusahaan berukuran kecil biasanya harga sahamnya rendah. Menurut Sukarno et al .(2020:67) ukuran perusahaan mempengaruhi positif terhadap harga saham, berarti semakin besar ukuran perusahaan maka harga sahamnya tinggi.

Besarnya profitabilitas yang diperoleh perusahaan menggambarkan kondisi perusahaan yang baik. Kondisi yang baik ini berpengaruh pada sekuritas para emiten di pasar modal sehingga dapat meningkatkan harga saham, jumlah permintaan dan volume perdagangan saham akan meningkat. Selain itu menurut Putranto dan Darmawan (2018:113), kenaikan laba mengakibatkan harga sahamnya tinggi.

\section{LANDASAN TEORI}

\subsection{Pengaruh Struktur Modal Terhadap Harga Saham}

Menurut Sampurno (2016:3) Investor tertarik debt to equity ratio (DER) rendah karena Entitas mampu menjalankan kegiatan dengan dananya sendiri tanpa berhutang sehingga DER memiliki pengaruh negatif terhadap harga saham. Menurut Junaeni (2017:33) DER yang tinggi akan mempengaruhi minat investor terhadap saham perusahaan, karena investor tidak tertarik pada saham yang menanggung terlalu banyak 
beban hutang. Menurut Lombogia et al. (2020:160) Perusahaan dengan lancara membayar kewajibannya menyebabkan Debt to equity ratio-nya menurun dapat meningkat harga saham tetapi hutang tinggi berakibat penurunan harga saham.

Berdasarkan pendapat di atas disimpulkan perusahaan memiliki DER rendah maka harga saham naik dan perusahaan DER tinggi maka harga saham turun.

\subsection{Pengaruh Ukuran Perusahaan Terhadap Harga Saham}

Menurut Nurlita dan Robiyanto (2018:618) Tingkat pengembalian saham yang lebih tinggi pada perusahaan skala besar dibandingkan skala kecil. Menurut Alamsyah (2019:171) Semakin besar perusahaan maka semakin besar invtestor untuk menanamkan sahamnya di bandingkan perusahaan kecil. Menurut Sukarno et al .(2020:67) ukuran perusahaan mempengaruhi positif terhadap harga saham, berarti semakin besar ukuran perusahaan maka harga sahamnya tinggi.

Berdasarkan pendapat di atas disimpulkan perusahaan berukuran besar maka harga saham tinggi begitu juga perusahaan berukuran kecil harga saham rendah.

\subsection{Pengaruh Profitabilitas Terhadap Harga Saham}

Menurut Zaki et al. (2017:59), peningkatan laba mengakibatkan tingginya harga sahamnya. Menurut Octaviani dan Komalasarai (2017:81), keseluruhan penurunan aktiva mengakibatkan kenaikan ROA kemudian mengakibatkan kenaikan harga saham. Menurut Putranto dan Darmawan (2018:113), kenaikan laba mengakibatkan harga sahamnya tinggi.

Berdasarkan pendapat di atas disimpulkan profitabilitas yang tinggi maka harga saham tinggi begitu juga profitabilitas rendah maka harga saham rendah.

\subsection{Kerangka Konseptual}

Kerangka konseptual dapat dilihat pada Gambar I.1:

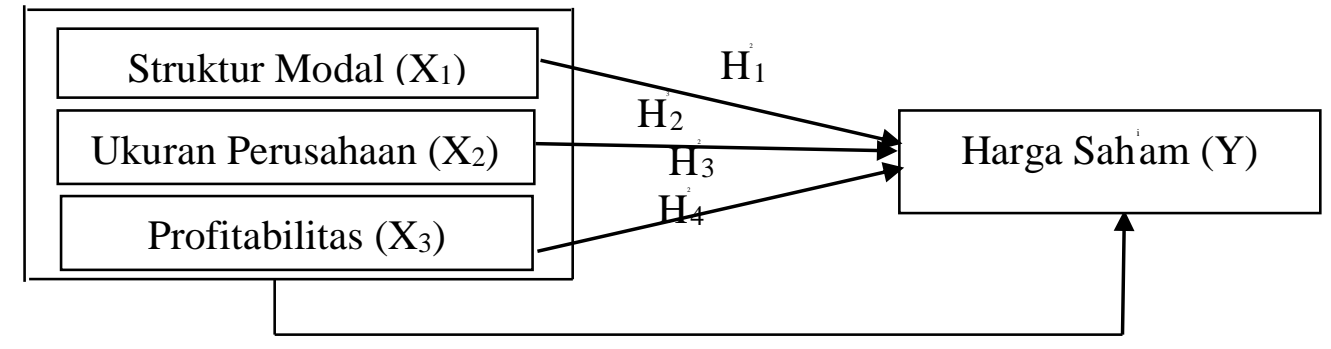

\section{Gambar I.1 Kerangka Konseptual}

\subsection{Hipotesis}

Hipotesis yang diteliti adalah sebagai berikut :

$\mathrm{H}_{1}$ : Struktur modal berdampak terhadap harga saham (Studi Kasus Pada Sub Sektor Makanan dan Minuman yang terdaftar Di Bursa Efek Indonesia).

$\mathrm{H}_{2}$ : Ukuran perusahaan berdampak terhadap harga saham (Studi Kasus Pada Sub Sektor Makanan dan Minuman yang terdaftar Di Bursa Efek Indonesia).

$\mathrm{H}_{3}$ : Profitabilitas berdampak terhadap harga saham (Studi Kasus Pada Sub Sektor Makanan dan Minuman yang terdaftar Di Bursa Efek Indonesia). 
$\mathrm{H}_{4}$ :Struktur modal, ukuran perusahaan dan profitabilitas berdampak terhadap harga saham (Studi Kasus Pada Sub Sektor Makanan dan Minuman yang terdaftar Di Bursa Efek Indonesia).

\section{METODOLOGI PENELITIAN}

Tempat penelitian dilakukan melalui website www.idx.co.id sebagai sumber untuk mengambil laporan keuangan pada perusahaan Intital Public Offering (IPO) dan mencatat sahamnya di Bursa Efek Indonesia dalam periode 2014-2018. Waktu penelitian dimulai bulan April hingga Desember 2020. Pendekatan kuantitatif yang digunakan dalam penelitian ini. Sifat penelitian kausalitas yang menunjukkan hubungan sebab akibat. Teknik pengumpulan data dokumentasi. Jenis data penelitian adalah data kuantitatif berupa angka. Sumber data penelitian berupa data sekunder. Data sekunder dalam penelitian ini meliputi studi dokumentasi.

Populasi dari penelitian ini adalah 26 Sub Sektor Makanan dan Minuman yang terdaftar Di Bursa Efek Indonesia Periode 2014-2018. Penelitian ini menggunakan metode Purposive sampling untuk menarik sampel, dengan kriteria sebagai berikut:

1. Sub Sektor Makanan dan Minuman di Bursa Efek Indonesia Periode 20142018.

2. Sub Sektor Makanan dan Minuman yang mempublikasikan laporan keuangan Periode 2014-2018.

3. Sub Sektor Makanan dan Minuman yang memiliki laba Periode 2014-2018. Adapun kriteria tertentu dalam pengambilan sampel pada tabel II.1 sebagai berikut:

Tabel II.1

Sampel Penelitian

\begin{tabular}{|l|l|c|}
\hline No. & Kriteria & Sampel \\
\hline 1. & $\begin{array}{l}\text { Sub Sektor Makanan dan Minuman di Bursa } \\
\text { Efek Indonesia Periode 2014-2018. }\end{array}$ & 26 \\
\hline 2. & $\begin{array}{l}\text { Sub Sektor Makanan dan Minuman yang tidak } \\
\text { mempublikasikan laporan keuangan Periode } \\
\text { 2014-2018. }\end{array}$ & (13) \\
\hline 3. & $\begin{array}{l}\text { Sub Sektor Makanan dan Minuman yang tidak } \\
\text { memiliki laba bersih positif berturut-turut } \\
\text { Periode 2014-2018. }\end{array}$ & (3) \\
\hline $\begin{array}{l}\text { Total sampel yang diteliti Periode 2014-2018 } \\
\text { (Perusahaan) }\end{array}$ & 10 \\
\hline Total sampel 10 x 5 tahun & 50 \\
\hline
\end{tabular}

Sampel penelitian sebanyak 10 perusahaan Sub Sektor Makanan dan Minuman Yang Terdaftar Di Bursa Efek Indonesia Periode 2014-2018 dengan sampel observasi pengamatan selama 5 tahun sehingga sampel berjumlah sebanyak 50 laporan keuangan Sub Sektor Makanan dan Minuman Yang Terdaftar Di Bursa Efek Indonesia Periode 2014-2018.

\section{HASIL PENELITIAN DAN PEMBAHASAN}

\subsection{Hasil Penelitian}

Pada penelitian ini sampel pada perusahaan sub sektor makanan dan minuman yang terdaftar di BEI yang berjumlah 10 perusahaan dengan periode penelitian dari tahun 
2014-2018, sehingga data penelitian yang diperoleh berjumlah 50. Pengujian penelitian ini menggunakan Uji Asumsi Klasik. Didalam Uji persyaratan analisis ini ada 4 yaitu pengujian normalitas, multikolinearitas, autokorelasi, dan heteroskedastisitas.

1. Uji Normalitas

Uji normalitas digunakan untuk menguji apakah dalam model regresi, variabel pengganggu atau residual memiliki distribusi normal. Hasil uji normalitas dapat diliat di bawah ini:

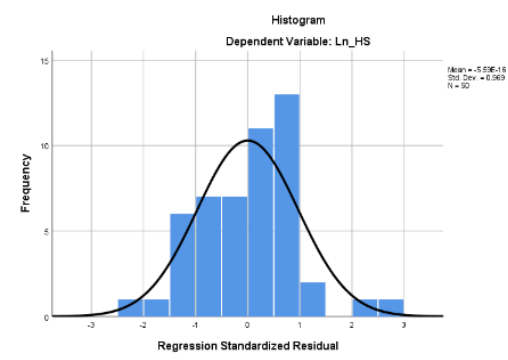

Gambar 4.1. Grafik Histogram

Sumber : Hasil Pengolahan Data SPSS

Dari gambar 4.1 menunjukkan garis kurva berbentuk simetri tidak miring ke kiri ataupun ke kanan maka terdistribusi datanya normal.

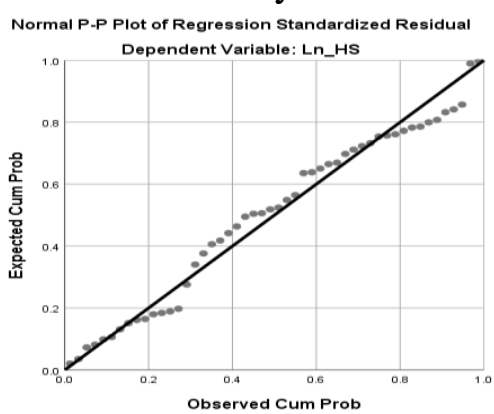

\section{Gambar 4.2. Grafik Probability Plot}

Sumber : Hasil Pengolahan Data SPSS

Grafik normalitas P-P Plot di Gambar 4.2, ditunjukkan titik mengikuti garis diagonalnya memenuhi normalitasnya.

Tabel 4.1One-Sample Kolmogorov-Smirnov Test

One-Sample Kolmogorov-Smirnov Test

\begin{tabular}{|c|c|c|}
\hline & e Kolmogorov-s & esidual \\
\hline$\overline{\mathrm{N}}$ & & 50 \\
\hline \multirow[t]{2}{*}{ Normal Parameters ${ }^{\mathrm{a}, \mathrm{b}}$} & Mean & .0000000 \\
\hline & Std. Deviation & 65689370 \\
\hline \multirow[t]{3}{*}{ Most Extreme Differences } & Absolute & .095 \\
\hline & Positive & .095 \\
\hline & Negative & -.080 \\
\hline Test Statistic & & .095 \\
\hline Asymp. Sig. (2-tailed) & & $.200^{\mathrm{c}, \mathrm{d}}$ \\
\hline
\end{tabular}

Sumber : Hasil Pengolahan Data SPSS

Hasil uji normalitas Kolmogorov Smirnovpada Tabel 4.1 ditunjukkan data yang diolah dengan SPSS memperlihatkan data normal dikarenakan Asymp signifikan sebesar 0,200 berada di atas 0,05.

2. Uji Multikolinieritas 
Uji multikolinearitas tujuannya untuk menguji ada atau tidaknya korelasi antar variable independen. Kriteria multikolonieritas dilakukan dengan melihat nilai VIF (Variance Inflation Factor) dan Tolerance

Tabel 4.2Hasil Uji Multikolinieritas

\begin{tabular}{ll|r|r}
\multicolumn{2}{c}{} & \multicolumn{2}{c}{ Collinearity Statistics } \\
Model & & Tolerance & \multicolumn{1}{c}{ VIF } \\
\hline 1 & (Constant) & & \\
\cline { 2 - 3 } & Ln_DER & .979 & 1.022 \\
\hline & Ln_UK & .972 & 1.029 \\
\hline Ln_ROA & .993 & 1.007 \\
\hline
\end{tabular}

Sumber : Hasil Pengolahan Data SPSS

Tabel 4.2 menunjukkan nilai Struktur modalnya, Ukuran perusahan, profitabilitasnya memiliki tolerance diatas 0,1 dan VIF dibawah 10 memperlihatkan tidak multikolinieritas.

3. Uji Autokorelasi

Uji autokorelasi menunjukkan ada tidaknya korelasi kesalahan pengganggu periode $\mathrm{t}$ terhadap kesalahan periode t-1. Kriteria bebas dari autokorelasi dengan Durbin Wattson :

\begin{tabular}{l|l|l|l|}
\multicolumn{5}{c}{ Tabel 4.3Hasil Uji Autokorelasi } \\
Model Summary
\end{tabular}

Dari tabel 4.3, menunjukkan nilai $\mathrm{Dw}=2,123, \mathrm{~N}=50, \mathrm{du}=1,6739$, dengan melihat kriteria pada pedoman Durbin-Watson maka nilai $\mathrm{du}<\mathrm{dw}<4-\mathrm{du}$, $1,6739<2,123<4-1,6739$ hingga $1,6739<2,123<2,3261$ maka kesimpulan tidak terjadi autokorelasi negatif maupun positif.

4. Uji Heteroskedastisitas

Pengujian ini dengan menggunakan grafik scatterplot antara standardized predicted value (ZPRED) dan studentiized residual (SRESID). Pengukurannya dengan grafik ada tidak pola heteroskedastisitas.

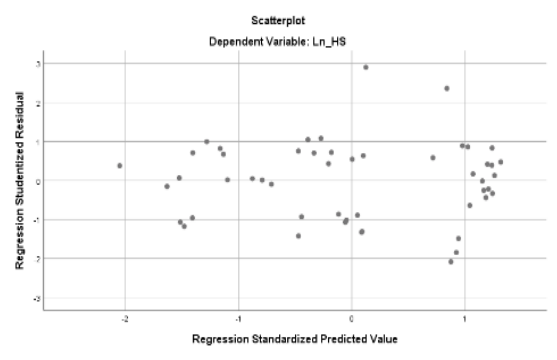

Gambar 4.3. Grafik Scaterplot Uji Heteroskedastisitas Sumber : Hasil Pengolahan Data SPSS

Dari gambar 4.3 Grafik Scaterplot terlihat bahwa titik-titik menyebar secara acak baik diatas maupun dibawah angka nol (0) pada sumbu Y, tidak berkumpul disatu 
tempat, sehingga dari grafik scaterplot dapat disimpulkan bahwa tidak terjadi heteroskedastisitas pada model regresi.

\section{IV.2. Analisis Linier Berganda}

Tabel 4.4 Hasil Analisis Regresi Linear Berganda

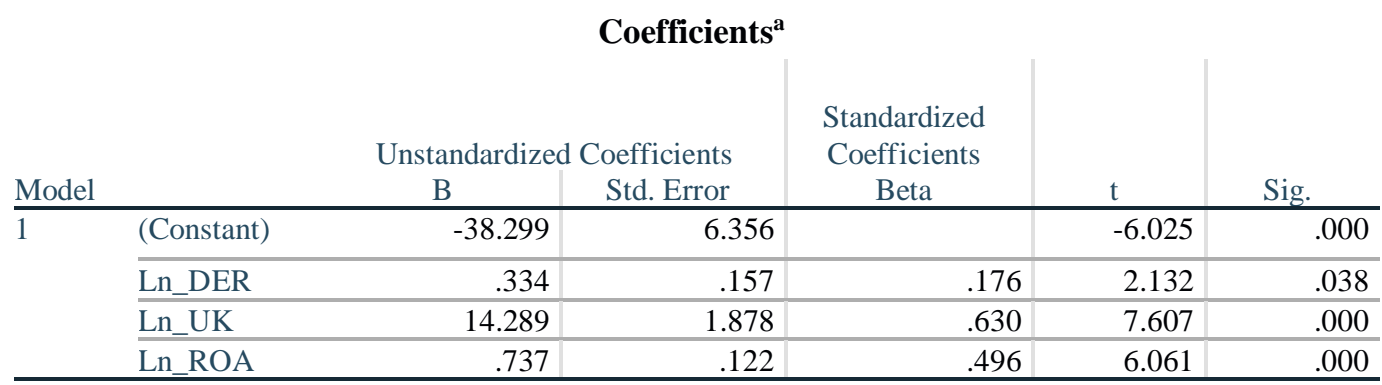

a. Dependent Variable: Ln_HS

Sumber : Hasil Pengolahan Data SPSS

Hasil analisis regresi linear berganda dapat dilihat pada tabel 4.4

Ln_Harga Saham $=-38,299+0,344$ Ln_Struktur Modal + 14,289 Ln_Ukuran

Perusahaan + 0,737 Ln_Profitabilitas

Hasil intrepretasi dari regresi tersebut adalah Konstanta sebesar -38,299 berarti struktur modal, ukuran perusahaan dan profitabilitasnya dianggap nol dengan harga sahamnya sebesar $-38,299$. Koefisien regresi Struktur modal sebesar 0,334 berarti meningkatnya struktur modal satu kali maka harga sahamnya meningkat sebesar 0,334. Koefisien regresi Ukuran perusahaan sebesar 14,289 berarti meningkatnya ukuran perusahaan satu kali maka harga sahamnya meningkat sebesar 14,289. Koefisien regresi Profitabilitas sebesar 0,737 berarti meningkatnya profitabilitas satu kali maka harga sahamnya meningkat sebesar 0,737 .

\section{IV.3. Koefisien Determinasi Hipotesis}

Tabel 4.5 Koefisien Determinasi

Model Summaryb

\begin{tabular}{lr|r|r|r} 
Model & R & R Square & Adjusted R Square & Std. Error of the Estimate \\
\hline 1 & $.833^{\mathrm{a}}$ & .694 & .674 & .67798 \\
\hline
\end{tabular}

a. Predictors: (Constant), Ln_ROA, Ln_DER, Ln_UK

b. Dependent Variable: Ln_HS

Sumber : Hasil Pengolahan Data SPSS

Pada tabel 4.5 diatas, nilai Adjusted R Squarenya sebesar 0,674 hal ini berarti mengindikasi bahwa variasi dari struktur modal, ukuran perusahaan dan profitabilitas menjelaskan harga saham dengan pengaruh sebesar $67,4 \%$ dan sisanya sebesar $32,6 \%$ dipengaruhi variabel lainnya.

\section{IV.4. Pengujian Hipotesis Secara Simultan (Uji F) \\ Tabel 4.6 Hasil Uji Statistik F \\ ANOVA $^{\mathrm{a}}$}




\begin{tabular}{llr|r|r|r|r} 
Model & \multicolumn{1}{c}{ Sum of Squares } & df & Mean Square & F & \multicolumn{1}{c}{ Sig. } \\
\hline 1 & Regression & 47.842 & 3 & 15.947 & 34.694 & $.000^{\mathrm{b}}$ \\
\hline Residual & 21.144 & 46 & .460 & & \\
\cline { 2 - 7 } & Total & 68.986 & 49 & & & \\
\hline
\end{tabular}

a. Dependent Variable: Ln_HS

b. Predictors: (Constant), Ln_ROA, Ln_DER, Ln_UK

Sumber : Hasil Pengolahan Data SPSS

Berdasarkan tabel 4.6 menghasilkan nilai $F_{\text {hitung }}=34,694$, sig $=0,000$ dan $\mathrm{F}_{\text {tabel }}(50-4=46)=2,81$. Fhitung $>\mathrm{F}_{\text {tabel }}$ yaitu 34,694 $>2,81$ terlihat $\mathrm{H}_{0}$ ditolak, $\mathrm{H}_{\mathrm{a}}$ diterima ditunjukkan struktur modal, ukuran perusahaan dan profitabilitas berpengaruh terhadap harga saham (Studi Kasus Pada Sub Sektor Makanan dan Minuman yang terdaftar Di Bursa Efek Indonesia).

\section{IV.5. Pengujian Hipotesis Secara Parsial (Uji t)}

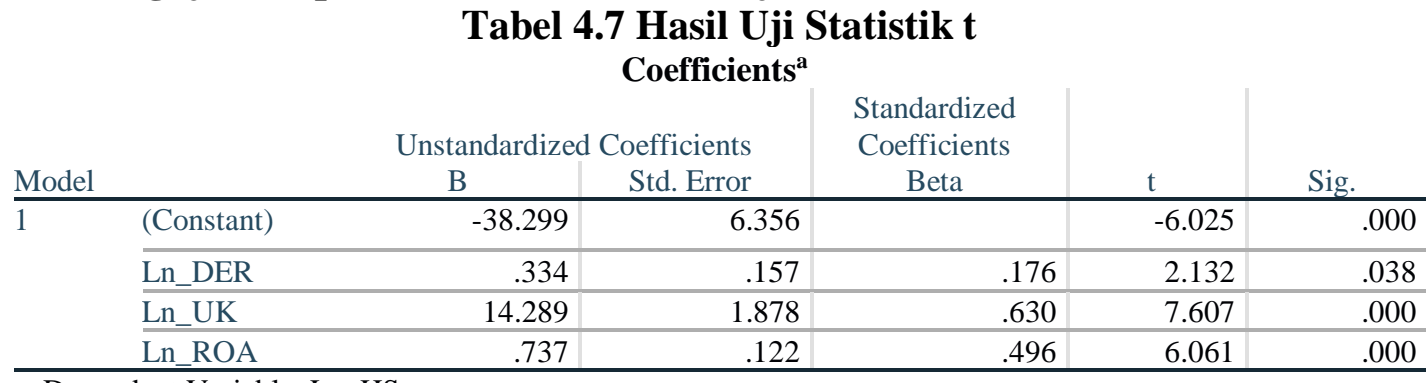

a. Dependent Variable: Ln_HS

Sumber : Hasil Pengolahan Data SPSS

Berdasarkan Tabel III.9 hasil dari Uji t dapat dijelaskan sebagai berikut:

1. Struktur modal thitung $=2,132$, sig $=0,038, t_{\text {tabel }}(50-3=47)=2,011$, $t_{\text {hitung }}>t_{\text {tabel, }}, 2,132$ $>$ 2,011 $\mathrm{H}_{0}$ ditolak, $\mathrm{H}_{\mathrm{a}}$ diterima ditunjukkan struktur modal berpengaruh terhadap harga saham (Studi Kasus Pada Sub Sektor Makanan dan Minuman yang terdaftar Di Bursa Efek Indonesia).

2. Ukuran perusahaan $t_{\text {hitung }}=7,607$, sig $=0,000$, $t_{\text {tabel }}(50-3=47)=2,011$, $t_{\text {hitung }}>t_{\text {tabel, }}$, 7,607> 2,011 $\mathrm{H}_{0}$ ditolak, $\mathrm{H}_{\mathrm{a}}$ diterima ditunjukkan ukuran perusahaan berpengaruh terhadap harga saham (Studi Kasus Pada Sub Sektor Makanan dan Minuman yang terdaftar Di Bursa Efek Indonesia).

3. Profitabilitas $\mathrm{t}_{\text {hitung }}=6,061$, $\mathrm{sig}=0,000, \mathrm{t}_{\text {tabel }}(50-3=47)=2,011, \mathrm{t}_{\text {hitung }}>\mathrm{t}_{\text {tabel, }}, 6,061>$ 2,011 $\mathrm{H}_{0}$ ditolak, $\mathrm{H}_{\mathrm{a}}$ diterima ditunjukkan profitabilitas berpengaruh terhadap harga saham (Studi Kasus Pada Sub Sektor Makanan dan Minuman yang terdaftar Di Bursa Efek Indonesia).

\section{IV.6. Pembahasan}

Hasil penelitian ini adalah struktur modal berpengaruh terhadap harga saham (Studi Kasus Pada Sub Sektor Makanan dan Minuman yang terdaftar Di Bursa Efek Indonesia). Struktur modal berpengaruh harga saham ditunjukkan struktur permodalan usaha lebih banyak memanfaatkan dana yang disediakan oleh kreditur dalam menghasilkan laba. Hasil penelitian konsisten dengan Sampurno (2016:3) Investor tertarik debt to equity ratio (DER) rendah karena perusahaan mampu menjalankan kegiatan dengan dananya sendiri tanpa berhutang sehingga DER memiliki pengaruh negatif terhadap harga saham. Hasil penelitian ini tidak sejalan dengan Putranto dan Darmawan (2018) yang menyatakan, Rasio leverage memiliiki dampak dengan cara negatif terhadap harga saham. 
Hasil penelitian ini adalah ukuran perusahaan berpengaruh terhadap harga saham (Studi Kasus Pada Sub Sektor Makanan dan Minuman yang terdaftar Di Bursa Efek Indonesia). Ukuran perusahaan berpengaruh terhadap harga saham mengambarkan penggunaan aset perusahaan yang baik dengan total aset perusahaan meningkat bahwa sumber dana perusahaan dapat memberikan tambahan keuntungan bagi perusahaan sehingga mempengaruhi harga saham yang beredar. Hasil penelitian ini konsisten dengan Nurlita et al. (2018:618) Tingkat pengembalian saham lebih tinggi pada perusahaan skala besar dibandingkan skala kecil. Hasil penelitian ini sejalan dengan Lombogia et al. (2020) menyatakan, ukuran perusahaan berpengaruh positif dan signifikan terhadap harga saham.

Hasil penelitian ini adalah profitabilitas berpengaruh terhadap harga saham (Studi Kasus Pada Sub Sektor Makanan dan Minuman yang terdaftar Di Bursa Efek Indonesia). Profitabilitas berpengaruh terhadap harga saham dikarenakan Return on Asset (ROA) meningkat dapat mempengaruhi harga saham juga naik sedangkan Return on Asset (ROA) mengalami penurunan dapat mempengaruhi harga saham juga turun. Laba besar memberikan dampak terhadap harga saham nilainya tinggi disebabkan perusahaan memiliki kemampuan mengelola kegiatan usahanya yang terlihat dari jumlah aset, jumlah laba. Hasil penelitian ini konsisten Zaki et al. (2017:59) Apabila laba suatu perusahaan meningkat, harga saham perusahaan tersebut juga akan meningkat. Hasil penelitian ini sejalan dengan Putranto and Darmawan (2018) yang menyatakan, Rasio profitability memiliki dampak terhadap harga saham dengan cara positif.

\section{KESIMPULAN}

Kesimpulan dari hasil penelitian ini secara parsialstruktur modal, ukuran perusahaan, dan profitabilitas berpengaruh terhadap harga saham (Studi Kasus Pada Sub Sektor Makanan dan Minuman yang terdaftar Di Bursa Efek Indonesia). Dan secara simultan struktur modal, ukuran perusahaan, dan profitabilitas berpengaruh terhadap harga saham (Studi Kasus Pada Sub Sektor Makanan dan Minuman yang terdaftar Di Bursa Efek Indonesia). Dengan hasil koefisien determinasi sebesar 0,674 hal ini berarti mengindikasi bahwa variasi dari struktur modal, ukuran perusahaan dan profitabilitas menjelaskan harga saham sebesar $67,4 \%$, sedangkan sisanya $32,6 \%$ dipengaruhi oleh variabel lain yang tidak diteliti.

\section{UCAPAN TERIMA KASIH}

Selama menyelesaikan penyusunan jurnal ini penulis telah banyak menerima bantuan dari berbagai pihak, baik secara langsung maupun tidak langsung. Untuk itu, dengan segala kerendahan hati.

\section{DAFTAR PUSTAKA}

Alamsyah, Muh. Fuad. 2019. Pengaruh profitabilitas, ukuran perusahaan dan nilai pasar terhadap harga saham pada sub sektor pertambangan logam dan mineral dibursa efek indonesia (BEI). Jurnal Manajemen-VOL.11 (2)2019, 170-178.Universitas Ichsan Gorontalo, Indonesia.

Fahmi, Irham. 2014. Pengantar Manajemen Keuangan Teori dan Soal Jawab. Bandung : Alfabeta. 
Hery. 2017. Teori Akuntansi Pendekatan Konsep dan Analisis. Jakarta : Penerbit PT Grasindo.

Junaeni, Irawati. 2017. Pengaruh EVA, ROA, DER dan TATO terhadap Harga Saham pada Perusahaan Makanan dan Minuman di BEI. Riset \& Jurnal Akuntansi. Volume2 Nomor1 Agustus2017. e-ISSN:2548-9224. Jakarta- Indonesia :Perbanas Institute, Economis and Business Faculty.

Kasmir. 2014. Analisis Laporan Keuangan.Jakarta : Penerbit Rajagrafindo Persada.

Lombogia, Adolf Jelly Glen; Chirike Vista dan Siti Dini. 2020. Pengaruh Current Ratio, Debt to Equity Ratio, Net Profit Margin, dan Ukuran Perusahaan Terhadap Harga Saham Pada Perusahaan Otomotif Dan Komponen Yang Terdaftar Di BEI Tahun 2013-2017. Jurnal Ekonomi \& Ekonomi Syariah Vol 3 No 1, Januari 2020. EISSN:2599-3410. Universitas Prima Indonesia.

Nurlita, Yunita dan Robiyanto. 2018. Pengaruh Current Ratio, DER, NPM, DAN Ukuran Perusahaan Yang Terdaftar Di Jakarta Islamic Index. Prosiding SENDI_U 2018. ISBN:978-979-3649-99. Universitas Kristen Satya Wacana.

Octaviani dan Komalasarai. 2017. Pengaruh Likuiditas, Profitabilitas, dan Solvabilitas Terhadap Harga Saham (Studi Kasus pada Perusahaan Perbankan yang Terdaftar di Bursa Efek Indonesia). Jurnal Akuntansi. Vol. 3 No. 2. Januari2017. pISSN2339-2436. e-ISSN2549-5968. Universitas Serang Raya.

Putranto, Ashari Dwi dan Ari Darmawan. 2018. Pengaruh Ukuran Perusahaan, Profitabilitas, Leverage, Dan Nilai Pasar Terhadap Harga Saham (Studi Kasus pada Perusahaan Pertambangan yang Terdaftar di Bursa Efek Indonesia Periode 2010-2016).Jurnal Administrasi Bisnis (JAB). Vol.56 No.1 Maret2018. Malang :Universitas Brawijaya.

Rodoni, Ahmad dan Ali, Herni. 2014. Manajemen Keuangan Modern. Jakarta : Penerbit Mitra Wacana Media

Sampurno Cathelia Nadia Djoko. 2016. Analisis Pengaruh ROE, DER, TATO, CAPEX Dan NCCR Terhadap Harga Saham (Studi Kasus pada Perusahaan Manufaktur Sektor Industri Barang Konsumsi yang terdaftar di Bursa Efek Indonesia Periode 2010-2014). Diponegoro Journal Of Management. Universitas Diponegoro. Volume 5, Nomor 3, Tahun 2016, Halaman 1-13. ISSN (Online): 2337-3792.

Sukarno, Muhammad; Riana Sitawatidan Sam'ani. 2016. Pengaruh Profitabilitas, Pertumbuhan Penjualan Dan Ukuran Perusahaan Terhadap Harga Saham Dengan Struktur Modal Sebagai Variabel Intervening (Studi Empiris Perusahaan LQ-45 Di Bursa Efek Indonesia).Dharma Ekonomi. No.44/ Th.XXIII/ Oktober 2016. ISSN: 0853-5205. STIE Dharmaputra Semarang.

Widioatmodjo, Sawidji. 2012. Cara Sehat Investasi Di Pasar Modal. Edisi Revisi. Jakarta : PT Elex Media Komputindo. 
Zaki,Islahuddin dan Shabri 2017. Pengaruh Profitabilitas, Leverage Keuangan Dan Ukuran Perusahaan Terhadap Harga Saham (Studi Pada Perusahaan Manufaktur Yang Terdaftar Di Bursa Efek Indonesia Periode 2005-2014). Jurnal Megister Akuntansi Pascasarjana Universitas Syiah Kuala. ISSN $2302-0164$. Universityin Banda Aceh. 